REFLECTIONS:

NEUROLOGY AND

THE HUMANITIES

Section Editor

Anne W. McCammon,

MD, FAAN

Beth James

\title{
Taking Emmanuel home
}

LUCK I believe many people who see the disheveled homeless man on their corner contemplate, at least once, bringing him home for a hot meal. Probably all young moms who see the beautiful city children playing around the traffic want to scoop them up and take them to the zoo. I'm quite sure many of my fellow physicians, nurses, and therapists want to bathe the dirty feet of the patient who is too disabled to do it for himself. My story then is not extraordinary in that it happened-but that it doesn't happen more often.

Emmanuel had an enigmatic smile. His teeth were beyond crooked and he hadn't been to a dentist in years. The beauty of his smile was that it conveyed the warmth and goodness in his soul so quickly and so freely to anyone who engaged him.

I met Emmanuel when he was 10 years old, recently brought from El Salvador to the United States by his mother. Their immigration history is complicated and not entirely legal. He had an older brother, who was a little sullen, a younger brother, who was adorable, and a charming, pregnant mother, Roberta. Roberta had brought Emmanuel to see me, a neurologist, because he had been diagnosed with Duchenne muscular dystrophy, before immigrating, and our clinic would see him without cost. In El Salvador, boys with Duchenne typically die as children. In the United States, they die in early adulthood.

Emmanuel was still walking when I met him and continued to walk until he was 13 years old. I prescribed prednisone, which is a few dollars a month, to help preserve muscle function, but was never convinced he was taking it as he didn't show the typical side effects. Later, I prescribed lisinopril, also a few dollars a month, to preserve cardiac function, but that prescription was not filled. I instructed the family repeatedly about stretching activities but I was never reassured these would happen. Roberta was a busy, single mother of 3, and then 4, boys. Luckily, none of the others had Duchenne. I would see Emmanuel infrequently and tell him he needed to take his meds and do the stretching activities. He would smile his beautiful smile, nod, and refuse to say anything negative.

Roberta began to bring Emmanuel into clinic less. She got behind on her rent payments and was facing eviction. The family lived in a second floor apartment and Emmanuel's big brother was responsible for carrying him up and down the stairs. But the electric wheelchair was too heavy to leave the apartment. Emmanuel missed a lot of school. He missed free Muscular Dystrophy Association camps. He later told me that during this time, the summer of his 15th year, he didn't leave the apartment from when school ended in the spring to when it began again in the fall. Without the help he needed to get from his bed to the bathroom, he would urinate in his bed. If he was given clothes to change into, it would take him over an hour to struggle to get them on by himself. He later told me that during this time he wanted to kill himself.

Emmanuel missed his appointment with me that fall. We rescheduled for early November. The morning of the appointment, he and his family did not show up again. I called Roberta and asked if she would be bringing him in.

"He's going to El Salvador," she said. "My father is going to take him tomorrow to live with my grandparents. It's all set up." I pleaded with her to bring him in so that I could see him and make sure that he had what he needed to make this one-way journey.

Sweet, beautiful, Emmanuel. His smile was as captivating as always and he still refused to say a negative word. His 100 -pound frame was down to 80 pounds. His scalp was flaking with dermatitis. His skin was sallow and dirty. He had an upper respiratory infection with cough. We asked Roberta to consider putting him in foster care now instead of sending him somewhere to live with elderly relatives where they would be less equipped to take care of a disease that only gets more difficult. Roberta refused for fear of getting deported herself. I told her my sincere medical opinion that if he were to go to El Salvador now, malnourished and with an upper respiratory infection, he would die soon.

"How do you know he won't die here?" she asked. My reaction was impulsive but as luck favors the prepared mind, my mind had been prepared to care for Emmanuel for years. And from the stories I brought home from the clinic to my husband, his mind had been prepared for my call.

Listen to the author read this story, available on the $\mathrm{iPad}^{\circledR}$ and Android ${ }^{\mathrm{TM}}$ devices.

This is a true story. All names have been changed. 
"Emmanuel's mother is planning on sending him to El Salvador where he will almost certainly not survive. Can we take him in?"

"Yes."

There was no discussion, reassurances, questions, and answers. There was no weighing of the pros and cons. There was my husband, immediately by my side, doing the right thing.

I've known some people who live by the creed of "appropriate boundaries." I thank God that they have never convinced me that boundaries are more important than intimacy. Emmanuel entered our home that night and permanently enriched our lives.

PLAYING CATCH UP When people ask me why, as a neurologist, I specialize in neuromuscular disorders, I answer that I was attracted to caring for these patients, in part, because the "disease does not define them." I think I must have heard that somewhere.

Dementia eventually defines the patient. He or she is no longer who he or she was but more like other patients with dementia. Schizophrenia, drug addiction, and other diseases of the brain and mind define the patient to many physicians. I thought patients with neuromuscular diseases were just like you and me: with a wide range of personalities, intelligences, likes, and dislikes, except they all struggled bravely and usually quietly with weakness. I now know that I was wrong. As Duchenne robbed Emmanuel of every reasonable expectation in life-to grow physically, to be loved by his family, to become independent-it developed in him extraordinary insight, courage, and gentleness that do indeed define him.

We had a lot of catching up to do. First, we needed to catch up on nutrition. I have never been a cook. I will eat cereal for dinner, or go without, before I will put a pan on the stove. The pleasure of feeding Emmanuel was immediate and immense and would turn anyone into a cook. The first few days he ate voraciously. He quickly regained his lost weight. He loved eating out at restaurants but thought little of our favorite Mexican restaurant, which he said was made by Gringos and served by Gringos.

Emmanuel's skin improved with nutrition. The flaking of his skin and scalp and the sallow color were gone within a couple of weeks. The dirty patches on his stomach and legs were harder to scrub off than I had imagined. We learned that loosening the layers of dead skin and dirt with Vaseline prior to bathing was more efficient and less uncomfortable than scrubbing. He liked to sit in the shower chair and have the warm water wash over him. Sometimes I'd hear him quietly singing songs from El Salvador.

There were fingernails and toenails to be trimmed and a good haircut needed. He cleaned up really well.
I learned to do his black hair into a "faux hawk" with a little gel so that he looked like one of his soccer heroes. We went shopping and picked out clothes that he liked and that would keep him warm. I snuck in a few Gringo clothes that I liked.

There were immunizations to catch up on and then the muscular dystrophy medications to start for earnest. There were eye examinations and glasses to be purchased. He had not been to a dentist since he came to the United States. As we were to find out, it is not easy to get free or inexpensive dental care. We tried the dental school and if anyone is able to get an appointment there they are more intelligent, resourceful, and definitely more patient than I am. Ultimately, we took him to my husband's dentist, who we knew did a lot of volunteer work. No questions asked, no request for contribution. My husband lifted Emmanuel onto the dental chair and a good cleaning and 4 fillings later, Emmanuel was good to go. Soon after he would get braces. His smile became that much more beautiful.

Emmanuel started going back to school. He had missed a third of the school days for that year and had incompletes and failed grades. But he had so charmed the administrators at his old school that despite now not being in the same district, they sent a wheelchair-accessible school bus to our home every morning to pick him up. He went to school every day. He came home and plodded through his school work, which was slow for him, only due to hand weakness. He caught up for weeks of missed school. He excelled.

FAMILY I had a daughter in grade school and a son in middle school. One day they came home from school and they had a stranger in a wheelchair living with them. They hadn't been given time for preparation, talks, and adjustment. They were told Emmanuel needed a home and would be living with us for a while. They nodded. The first couple of dinners, my son made little eye contact and no conversation. As far as I know, Emmanuel and my son never had a heart-to-heart, yet through video games, music, and some secret language of male adolescents they became almost as brothers, riding through the neighborhood together on the electric wheelchair. Many nights, raucous, uncontrollable laughter came from the converted sunroom that was Emmanuel's bedroom and the room for boy play.

My daughter loved Emmanuel from day one. She introduced him to her friends, included him in her activities, helped him with tasks that he needed physical help with, and generally nurtured him. We had "spa day" in which my daughter and I did his nails and gave him a facial. Emmanuel suggested we do that again. At some point, she began to love him as 
a brother. Since Emmanuel couldn't wrap his arms around her, they developed a neck hug that resembled 2 birds.

My husband bore the brunt of physical work related to Emmanuel. He lifted him on and off the toilet, on and off the bed, and because we didn't have a shower downstairs, up and down the stairs a couple of times a week. My husband has an odd sense of humor. No one else in the immediate family finds this humor funny. Emmanuel laughed hysterically with him. At first, I assumed Emmanuel was humoring my husband, as he was clearly humoring me with my cooking. However, as Emmanuel began to trade "dumb jokes" back and forth at a rapid pace with my husband, I understood that he was genuinely enjoying this interaction with my husband. They have a special bond that my husband does not share with anyone else in the family. As I lay in my bed reading, I loved the sound of Emmanuel and my husband joking around during the twice-a-week shower.

POSTSCRIPT Patience, forgiveness, and appreciation. These were some of the virtues Emmanuel began to teach us. He won the "Unsung Hero" award at high school graduation and he proudly led his class to the podium. He is living on campus at college now. We remember our lucky day when Emmanuel bravely decided to go live with his doctor whom he had met only a half dozen times before. Emmanuel rolled through the front door of our house and transformed our lives.

\section{ACKNOWLEDGMENT}

The author thanks Mary Gutmann for editorial suggestions. 


\section{Neurology}

Taking Emmanuel home

Beth James

Neurology 2016;87;e71-e73

DOI 10.1212/WNL.0000000000002998

This information is current as of August 22, 2016

\section{Updated Information \&} Services

Permissions \& Licensing

Reprints including high resolution figures, can be found at: http://n.neurology.org/content/87/8/e71.full

Information about reproducing this article in parts (figures,tables) or in its entirety can be found online at:

http://www.neurology.org/about/about_the_journal\#permissions

Information about ordering reprints can be found online:

http://n.neurology.org/subscribers/advertise

Neurology ${ }^{\circledR}$ is the official journal of the American Academy of Neurology. Published continuously since 1951, it is now a weekly with 48 issues per year. Copyright @ 2016 American Academy of Neurology. All rights reserved. Print ISSN: 0028-3878. Online ISSN: 1526-632X.

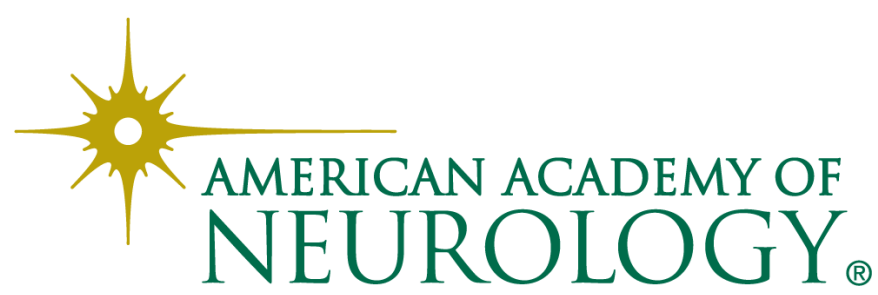

